

Figure (Case 2) Blood levels of active chloramphenicol during treatment with chloramphenicol $100 \mathrm{mg} / \mathrm{kg}$ per $24 \mathrm{~h}$ plus phenobarbitone $10 \mathrm{mg} / \mathrm{kg}$ per $24 \mathrm{~h}$. Blood levels were measured before and one hour after the 12 midday dose.

decline in chloramphenicol blood levels despite sustained IV treatment in high dosage. This decrease is probably explained by the induction of hepatic microsomal enzymes by phenobarbitone. Increased glucuronidation of chloramphenicol and a consequent decrease in therapeutic activity have been demonstrated in rats pretreated with phenobarbitone (Bella et al., 1968).

The conventional chloramphenicol dose for meningitis and septicaemia is $50-100 \mathrm{mg} / \mathrm{kg}$ per $24 \mathrm{~h}$ in infants and children. A lower dose is usually recommended for neonates whose renal and liver immaturity delays chloramphenicol excretion, but Black et al. (1978) showed that doses of up to 95 $\mathrm{mg} / \mathrm{kg}$ per $24 \mathrm{~h}$ may be needed to maintain therapeutic blood levels in this age group also. Our two patients show that during treatment with phenobarbitone even the maximum recommended dose of chloramphenicol, $100 \mathrm{mg} / \mathrm{kg}$ per $24 \mathrm{~h}$, may be insufficient to maintain peak blood levels within the therapeutic range $15-25 \mathrm{mg} / \mathrm{l}$. We therefore recommend that in all patients who receive enzymeinducing anticonvulsants (Conney, 1967), chloramphenicol blood levels should be measured every one or 2 days to avoid the hazards of excessive or inadequate dosage. It is possible that newer anticonvulsants with less enzyme-inducing activity, such as sodium valproate, will prove to have less effect on chloramphenicol metabolism than phenobarbitone.

We thank Mrs Barbara Tennant for secretarial help.

\section{References}

Bella, D. D., Ferrari, V., Marca, G., and Bonanomi, L. (1968). Chloramphenicol metabolism in the phenobarbitalinduced rat. Comparison with thiamphenicol. Biochemical Pharmacology, 17, 2381-2390.

Black, S. B., Levine, P., and Shinefield, H. R. (1978). The necessity for monitoring chloramphenicol levels when treating neonatal meningitis. Journal of Pediatrics, 92, 235-236.

Conney, A. H. (1967). Pharmacological implications of microsomal enzyme induction. Pharmacological Reviews, 19, 317-366.

Louie, T. J., Tally, F. P., Bartlett, J. G., and Gorbach, S. L. (1976). Rapid microbiological assay for chloramphenicol and tetracyclines. Antimicrobial Agents and Chemotherapy, 9, 874-878.

Correspondence to Dr M. H. Winterborn, East Birmingham District General Hospital, Bordesley Green East, Birmingham B9 5ST.

\title{
Food allergy
}

\section{Response to treatment with sodium cromoglycate}

\section{J. B. G. WATSON AND J. TIMMINS}

Departments of Paediatrics and Pharmacy, Children's Hospital, Sheffield

SUMMARY Two children with food allergy could not be successfully managed on dietary restriction alone. There was a good response to treatment with oral sodium cromoglycate but none to placebo treatment. The use of sodium cromoglycate in the management of food allergy should be studied further.

Allergy to cows' milk and other foodstuffs presents a difficult problem in diagnosis and management in children. Diagnostic criteria were discussed by
Walker-Smith (1975). Reports by Freier and Berger (1973) and Kuzemko and Simpson (1975) suggested that treatment with oral sodium cromoglycate might relieve symptoms. Two children are reported who demonstrated specific food intolerance, and their response to treatment with oral sodium cromoglycate is described.

\section{Case reports}

Case 1. A baby girl was breast fed for the 1st month 
of life and subsequently was given a dried milk (Ostermilk). After the change to artificial feeding her weight gain was unsatisfactory and she had persistent respiratory symptoms. When the patient was oneyear old, her mother concluded that the child was allergic to milk and discontinued milk feeds. There was an almost immediate cessation of symptoms and her rate of weight gain returned to normal. She returned to milk-containing products in her diet at age 2 years. After this she developed eczema which did not respond well to local treatment. She had recurrent episodes of abdominal pain and loose stools. Attempts to eliminate milk from her diet were unsuccessful as she had access to milk products in neighbours' houses and from other children. Eczema, abdominal pain, and diarrhoea were her most significant symptoms and their severity was related to ingestion of milk products or milk. Immunoglobulin studies showed a slightly raised serum IgE of $240 \mathrm{IU} / \mathrm{ml}$ (normal 20-120 IU $/ \mathrm{ml}$ ) at age $4 \frac{1}{4}$ years. $\mathrm{C} 3, \mathrm{C} 4$, and $\mathrm{C} 1 \mathrm{INH}$ were normal.

Treatment with oral sodium cromoglycate $100 \mathrm{mg}$ four times daily was begun at age $4 \frac{1}{4}$. After one year there was a significant improvement in her overall state of health. The eczema had disappeared; her previously dry and ichthyotic skin became normal. Her diet at this time included milk-containing products-butter, bread, coffee, cakes, milk chocolate-and these were well tolerated without adverse reaction. Her weight had increased from the 3 rd to the 10th centile. After one year it was decided to test her dependence on the treatment in the hope that it could be discontinued. Therefore, alternate episodes of treatment with sodium cromoglycate capsules and placebo capsules were given. During the period of placebo treatment, her eczema and gastrointestinal symptoms returned and she became a miserable, irritable child. During treatment with sodium cromoglycate she remained well. It was therefore decided that she should continue with the sodium cromoglycate orally indefinitely.

Case 2. A boy had severe eczema from age 2 years. He developed asthma at 7 and at about this age had a severe urticarial rash on several occasions. The rash was related to the ingestion of certain foodstuffs: pork, bacon, tomato soup, sage and onion stuffing, fish. Serum immunoglobulin and complement studies were normal. In view of the history he was given $100 \mathrm{mg}$ sodium cromoglycate orally before ingestion of a known allergen (sage and onion stuffing) and he developed a mild urticarial reaction. He was subsequently given $200 \mathrm{mg}$ oral sodium cromoglycate and after ingesting the same allergen he had no reaction. He was next treated for one week with sodium cromoglycate $200 \mathrm{mg}$ orally, four
Table (Case 2) Response to treatment with sodium cromoglycate (oral)

\begin{tabular}{|c|c|c|c|}
\hline $\begin{array}{l}\text { Sodium cromoglycate } \\
\text { (oral) }\end{array}$ & Alle & zens & Response \\
\hline None & \multicolumn{2}{|c|}{$\begin{array}{l}\text { Sage and onion } \\
\text { stuffing }\end{array}$} & Severe urticaria \\
\hline $\begin{array}{l}100 \mathrm{mg} \\
200 \mathrm{mg} \\
200 \mathrm{mg} 4 \text { times }\end{array}$ & ", & " & $\begin{array}{l}\text { Mild urticaria } \\
\text { None }\end{array}$ \\
\hline daily $\times 1 / 52$ & \multicolumn{2}{|c|}{$\begin{array}{l}\text { Bacon } \\
\text { Tomato soup }\end{array}$} & $\begin{array}{l}\text { Mild } \\
\text { Mild }\end{array}$ \\
\hline Placebo $\times 1 / 52$ & \multicolumn{2}{|c|}{$\left.\begin{array}{l}\text { Fish } \\
\text { Bacon } \\
\text { Pork }\end{array}\right\}$} & $\begin{array}{l}\text { Brisk reactions each } \\
\text { day }\end{array}$ \\
\hline
\end{tabular}

times daily. Then, after a week of no treatment he was treated with placebo. During the period of treatment with sodium cromoglycate he had no episodes of urticaria, but while taking the placebo these occurred severely each day (Table). He has since remained on sodium cromoglycate $200 \mathrm{mg}$ orally, four times daily. His eczema has resolved and he has no episodes of urticaria, except when he forgets his treatment. On starting the sodium cromoglycate he had transient mild swelling of his face which settled in a few days.

\section{Discussion}

The range of symptoms which can occur as a result of exposure to food allergens include anaphylactic shock, asthma, rhinitis, urticaria, eczema, and gastrointestinal disturbances (Blanckaert et al., 1975). The clinical diagnosis was established by the absence of symptoms after dietary elimination of the allergen, and recurrence of symptoms after reintroduction of the allergen. Elimination of specific allergens from the diets of young children is difficult to achieve as the child will accept food given to him by other children, neighbours, and friends unaware of the restrictions. Oral sodium cromoglycate offers a possibility of protection from food allergens as its mechanism of action lies in the inhibition of degranulation of mast cells, preventing the release of histamine and slow reacting substance $A$ (Werthenschlag, 1975). It has been reported (Moss et al., 1971) that less than $2 \%$ of orally-administered sodium cromoglycate is absorbed. It is probable that allergic symptoms are prevented by the unabsorbed portion of the drug passing through the gut. No large-scale study has been reported on the use of oral sodium cromoglycate in the management of cows' milk or other food allergy, but these observations demonstrate its usefulness in specific cases.

We thank Professor R. D. G. Milner for help and permission to present these cases, Fisons Ltd for 
supplies of oral sodium cromoglycate, and Drs A. Milford Ward and J. Watkins of the Department of Immunology, Hallamshire Hospital, Sheffield.

\section{References}

Blanckaert, D., Pont, J., Luis, J., Razeman-Pinta, M., Farriaux, J-P., and Fontaine, D. (1975). Une observation d'allergie alimentaire. Revue de pédiatrie, 11, 311-314.

Freier, S., and Berger, H. (1973). Disodium cromoglycate in gastrointestinal protein intolerance. Lancet, 1, 913-915.

Kuzemko, J. A., and Simpson, K. R. (1975). Treatment of allergy to cows' milk. Lancet, 1, 337-338.
Moss, G. F., Jones, K. M., Ritchie, J. T., and Cox, J. S. G. (1971). Plasma levels and urinary excretion of disodium cromoglycate after inhalation by human volunteers. Toxicology and Applied Pharmacology, 20, 147-156.

Walker-Smith, J. (1975). Cows' milk protein intolerance. Archives of Disease in Childhood, 50, 347-350.

Werthenschlag, J. (1975). Letter: Les allergies d'origine alimentaire. Intérêt du cromoglycate de sodium par voie buccale. Nouvelle presse médicale, 4, 1043.

Correspondence to Dr J. B. G. Watson, Department of Paediatrics, Children's Hospital, Western Bank, Sheffield S10 2TH. 